\title{
РОЗДІЛ І. ІСТОРІЯ УКРАЇНИ
}

УДК 94(477.41)《11/12»

\section{Колибенко Олена,}

кандидат історичних наук, доцент кафедри історії та культури України

olenkakolybenko@gmail.com

https://orcid.org/0000-0002-4009-5417

ДВН3 «Переяслав-Хмельницький

державний педагогічний університет імені

Григорія Сковороди»,

вул. Сухомлинського, 30,

м. Переяслав-Хмельницький,

Київська обл., Україна, 08401

\section{Колибенко Олександр,}

кандидат історичних наук, професор,

заступник генерального директора

3 наукової роботи

kolybenko@gmail.com

https://orcid.org/0000-0001-8616-9074

Національний історико-етнографічний заповідник «Переяслав»,

вул. Шевченка, 8, м. ПереяславХмельницький,

Київська обл., Україна, 08400

\section{DOI https://doi.org/10.31470/2415-3567- 2019-45-5-17}

\section{Kolybenko Olena,}

Candidate of Historical Sciences, assistant

professor of Department

of History and Culture of Ukraine

olenkakolybenko@gmail.com

https://orcid.org/0000-0002-4009-5417

Pereiaslav-Khmelnytskyi Hryhorii

Skovoroda State Pedagogical University,

30, Sukhomlynsky Str., PereiaslavKhmelnytskyi,

Kyiv region, Ukraine, 08401

\section{Kolybenko Oleksandr,}

Candidate of Historical Sciences, professor, Scientific work Deputy of the General Director kolybenko@gmail.com

https://orcid.org/0000-0001-8616-9074

National Historical and Ethnographic

Reserve «Pereiaslav»

8 , Shevchenka Str.,

Pereiaslav-Khmelnytskyi,

Kyiv region, Ukraine, 08400

\section{ПЕРЕЯСЛАВСЬКИЙ КНЯЗЬ МИХАЙЛО ВСЕВОЛОДОВИЧ: СЛАВНА СМЕРТЬ ПІСЛЯ БЕЗСЛАВНОГО ЖИТТЯ}

У статті здійснено спробу проаналізувати життєвий шлях одного з князів, щуо займав княжий стіл Переяславля Руського на початку ХІІІ cm. Це був Михайло Всеволодович, один із синів чернігівського князя Всеволода Святославича. Він розпочинав свою княжу кар'єру з Переяславля Руського у 1206 роиі. Це стало наслідком виграшу його батьком боротьби за київський престол та вигнання з Переяславля Руського князя Ярослава Всеволодовича.

Найбільш вірогідною датою народження Михайла Всеволодовича слід вважати 1188-1189 роки. У 1223 р. Михайло Всеволодович разом з іншими південними князями радився у Києві з приводу першої появи монголо-татар біля південних кордонів Русі. Потім він приймав участь у битві на Калці, після чого зайняв чернігівський стіл.

Михайло Всеволодович, як $i$ багато інших князів, мав складні стосунки 3 Новгородом. Його перше княжіння у Новгороді спочатку проходило добре, однак у 1225 р. він несподівано вирішив повернутися до Чернігова. Очевидно, він зробив ией крок за домовленістю з володимиро-суздальським князем Юрієм Всеволодовичем.

Вдруге Михайло Всеволодович зайняв новгородський стіл у 1228 рочі, одразу розпочавши низку реформ та змін у Новгороді. Він провів зміни у новгородській адміністрації - змінив посадника. Новгородський архієпископ Арсеній також втратив свою архієпископську кафедру. Спочатку на повернули на його місие колишнього 
архієпископа Антонія, але через немічність він не міг виконувати свої обов'язки. Новим новгородським архієпископом став диякон иеркви святого Георгія Спиридон.

Михайло Всеволодович залишив свій помітний слід в історії, ставши одним із небагатьох руських князів - мучеників за віру періоду монгольського нашестя.

Джерела повідомляють, щзо Михайло Всеволодович відмовився виконати язичницький обряд очищення вогнем. Його загибель - ие один з рідкісних випадків смерті від рук татар через релігійні переконання. Значно вагомімими причинами його вбивства були знищення татарських послів у Києві та спроба організації антитатарської коаліиії на 3аходi.

Отже, колишній переяславський князь Михайло Всеволодович за свого життя не зміг набути слави своїх відомих попередників на княжому столі Переяславля Руського Всеволода Ярославича, Володимира Мономаха, Ізяслава Мстиславича чи Володимира Глібовича. Однак обставини його смерті як мученика за віру дозволили йому стати одним із найвідоміших руських князів та бути зарахованим до лику святих. Завдяки иьому у XVI cm. Михайло Всеволодович отримав величезну кількість нащадків з числа княжих та дворянських родів з півночі колишньої Чернігівської землі.

Михайло Всеволодич Чернігівський був канонізований, отримав «офіційний» ореол мученика за віру.

Ключові слова: Михайло Всеволодович, переяславський князь, Переяславль Руський, Київ, Новгород, Чернігів, Всеволод Святославич, святий.

\section{PRINCE OF PEREIASLAV MYKHAILO VSEVOLODOVYCH: GLORIOUS DEATH AFTER AN UNHOLY LIFE}

The article attempts to analyze the life path of one of the princes, who occupied the princely table of Pereiaslavl of Rus' in the beginning of the XIII century. It was Mykhailo Vsevolodovych, one of the sons of Chernihiv prince Vsevolod Svyatoslavych. He began his career as a prince from Pereiaslavl of Rus' in 1206. This was the result of the victory of his father in the struggle for the throne of Kyiv and the expulsion from Pereiaslavl of Rus' prince Yaroslav Vsevolodovych.

The most probable date of birth of Mykhailo Vsevolodovych should be considered 11881189 years. In 1223, Mykhailo Vsevolodovych, together with other southern princes, consulted in Kyiv about the first appearance of the Mongol-Tatars near the southern borders of Rus'. Then he took part in the battle at Kalka, after which he took the Chernihiv table.

Mykhailo Vsevolodovych, like many other princes, had a difficult relationship with Novgorod. His first reign in Novgorod initially went well, but in 1225 he unexpectedly decided to return to Chernihiv. Obviously, he made this step in agreement with Volodymyr-Suzdal Prince Yuri Vsevolodovych.

For the second time Mykhailo Vsevolodovych took the Novgorod table in 1228, immediately starting a series of reforms and changes in Novgorod. He made changes in the Novgorod administration - he changed the posadnik. Archbishop Arseny of Novgorod also lost his archbishopric chair. Originally returned to his place by the former Archbishop Anthony, but due to his infirmity, he could not perform his duties. The deacon of the church of St. George Spyrydon became the new archbishop of Novgorod.

Mykhailo Vsevolodovych left his remarkable mark in history, becoming one of the few princes of Rus' - martyrs for the faith of the period of the Mongol invasion.

Sources say that Mykhailo Vsevolodovych refused to fulfill the pagan rite of purification by fire. His death is one of the rare deaths from the hands of the Tatars through religious beliefs. The more significant reasons for his assassination were the destruction of Tatar ambassadors in Kyiv and the attempt to organize an anti-Tatar coalition in the West.

Thus, the former Pereiaslavl Prince Mykhailo Vsevolodovych for his life was not able to gain the glory of his famous predecessors at the princely table of Pereiaslavl of Rus' - Vsevolod 
Yaroslavych, Volodymyr Monomakh, Izyaslav Mstyslavych or Volodymyr Hlibovych. However, the circumstances of his death as a martyr for faith allowed him to become one of the most famous princes of Rus' and to be credited to the saints. Due to this in the XVI century. Mykhailo $V$ sevolodovych received a huge number of descendants from among the princes and aristocratic families from the north of the former Chernihiv land.

Mykhailo Vsevolodovych of Chernihiv was canonized, received an "official» halo of the martyr for faith.

Key words: Mykhailo Vsevolodovych, Pereiaslav prince, Pereiaslavl of Rus', Kyiv, Novgorod, Chernihiv, Vsevolod Svyatoslavych, holy.

Одним із найвідоміших давньоруських князів, який недовго княжив у Переяславі на початку XIII ст., був Михайло Всеволодович, - син Всеволода Святославича Чермного (Буй-Тура Всеволода із «Слова о полку Ігоревім»). М.Ф. Котляр так стисло характеризує його: «МИХАЇЛ ВСЕВОЛОДИЧ (р. н. невід. - п. 20.09.1246) - князь черніг., новгород., галицький і київський; другий син кн. Всеволода Святославича Чермного і доньки (незнаної на ім'я) краківського кн. Казимира II Справедливого. Був типовим представником князівського стану доби удільної роздробленості: усе життя воював 3 ін. князями, охоче розпалював усобиці, користався 3 половецької допомоги для зведення рахунків із суперниками» [6, с. 687]. Таким чином, названий автор не визнає його переяславським князем.

Однак, Михайло Всеволодович все ж став 1206 р. переяславським князем. Це стало наслідком виграшу його батьком боротьби за київський престол та вигнання ним 3 Переяславля Руського Ярослава Всеволодовича - сина володимиро-суздальського князя Всеволода Юрійовича: «Осенью, 1205 года, Ярослав Всеволодович оставил Переяславль и ушел к своему отцу, в Суздаль. ... В Переяславле южном был посажен теперь Михаил Всеволодович, сын Всеволода Чермного. Таким образом южная Русь мало-по-малу начинает переходить под власть Ольговичей.

Впрочем, торжество В. Чермного было непродолжительным. В том же, 1206-м году, Рюрик Ростиславич, в союзе с Мстиславом Романовичем, своими сыновьями и племянниками, получив кроме того подкрепление со стороны половцев, напал на Киев и выгнал оттуда Всеволода Чермного. Той же участи подвергся и его сын, Михаил, сидевший в Переяславле.

Ставши вновь киевским князем, Рюрик посадил в Переяславле своего сына, Владимира Рюриковича» [9, с. 370].

Думку В.Г. Ляскоронського підтримує й М.М. Корінний: «Не просидев и года, сын Всеволода Чермного Михаил вынужден был уступить свое место в Переяславе сыну нового киевского князя Рюрика Ростиславича - Владимиру» [5, с. 66-67].

Метою даної статті є спроба проаналізувати життєвий шлях одного з переяславських князів початку XIII ст. - Михайла Всеволодовича, який у історіографії отримав прізвисько - Чернігівський.

Про дату народження Михайла Всеволодовича науковці досі сперечаються. На нашу думку, найбільш реальну дату наводить С. Павленко, який піддав сумніву точки зору В.М. Татіщева (1179 р.) та Г. Власьєва (1196р.): «У 1179 році, як повідомляє літопис, «привів Святослав [Всеволодович] за Всеволода, за середнього сина, жону з Ляхів, [Марію] Казимірівну, у Філіппів піст». Шлюб між чернігівським князем Всеволодом Святославовичем Чермним (Рудим) і донькою великого князя польського Казиміра II Справедливого Марії-Анастасії продовжив рід Ольговичів.... Дослідник Г.Власьєв зробив припущення, що Михайло Всеволодович народився наприкінці XII століття, близько 1196 року. На нашу думку, ця подія відбулась значно раніше - орієнтовно у кінці 1180-х років. 
Син Михайло був уже другою або й третьою дитиною у молодій сім’ї. Дату його народження визначаємо гіпотетично. Князі, як правило, тоді одружувалися в 15-17 літ, їхніми нареченими ставали 13-14-літні князівни.

Михайло взяв шлюб з Оленою, дочкою галицько-волинського князя Романа Мстиславовича. Сталася ця подія, за нашими висновками, десь у 1204-1205 році. Адже саме у 1204 році княжий стіл у Чернігові зайняв його батько Всеволод Чермний, і тоді йому було вигідно заради князівської дипломатії породичатися 3 впливовим недавнім ворогом - Романом Мстиславовичем, 3 яким велись переговори про мир. Невдовзі ситуація різко змінилась. Адже Роман Мстиславович 19 червня 1205 року загинув у бою з поляками. Якщо припустити, що у той час княжичу Михайлу було 16-17 років, то він народився відповідно у 1188-1189 роках. На це вказує і друга важлива деталь - батько у 1206 році посадив його княжити у Переяславі. Згаданий впливовий князівський стіл Всеволод Чермний не міг би доручити княжичу віком 10-11 років, бо не мав у тій захопленій землі надійної підтримки.

На перший погляд, народження у 1212 році у сім’ї князя Михайла Феодулії, орієнтовно у 1213 році Марії, потім синів Ростислава (1223), Юрія (1227?) та Мстислава, Симеона, Романа підтверджує припущення згаданого раніше дослідника Г.Власьєва про дати народження святого у середині 1190 -х років. У зв'язку з цим слід врахувати і таку обставину: у житії про черницю Єфросинію Суздальську (тобто про дочку Михайла Всеволодовича Феодулію, яка пішла у монастир) йдеться про те, що довго у князя Михайла «супруга бе неплоды», і тому перша донька з'явилася на світ лише після поїздки подружжя

Таким чином найбільш вірогідною датою народження Михайла Всеволодовича слід вважати 1188-1189 роки» [10, с. 6-7].

За Л.Є. Махновцем, Михайло Всеволодович був почергово князем переяславським, князем новгородським, князем галицьким, князем чернігівським, великим князем київським (середина березня 1238 р. - осінь 1239 р.; квітень 1241 р. - весна 1243 р.) [8, с. 497]. На думку Л.В. Войтовича, у 1210-1223 рр. він тримав якесь князівство із центром поблизу Чернігова [1, с. 408]. В.В. Богуславський вважає, що це було Новгород-Сіверське князівство. У 1223 р. Михайло Всеволодович був разом з іншими південними князями у Києві на раді з приводу першої появи монголо-татар біля південних кордонів Русі. Потім він приймав участь у битві на Калці, де загинув його дядько, чернігівський князь Мстислав Святославич, після чого Михайло Всеволодович зайняв чернігівський стіл. Характеризуючи учасників цієї ради, Д.Г. Хрустальов дає й коротку характеристику Михайлові Всеволодовичу: «Михаил Всеволодович (†1245), сын киевского и черниговского князя Всеволода Святославича Чермного. Чем владел до 1223 г. неизвестно; некоторое время в 1206 г. сидел в Переяславле Русском. После гибели на Калке дяди Мстислава Святославича занял Чернигов, который сохранил в качестве стольного града до своей смерти. Впоследствии принимал активное участие в борьбе за Киев, Новгород и Галич, в каждом из которых успел покняжить» $[18$, с. 65].

Михайло Всеволодович, як і багато інших руських, у тому числі й переяславських, князів, мав свою «історію» 3 Новгородом. В цій «історії» було багато різного й не зовсім зрозумілого для дослідників XIX - початку XXI ст., хоча, можливо, зовсім інакше це сприймалося сучасниками тих подій. Це дозволило П.П. Толочку, який присвятив Михайлу Всеволодовичу окремий розділ у своїй праці про взаємозв'язки Києва та Новгорода у X-XIII ст., вважати, що новгородська княжа кар'єра названого князя «во многом нелогичная и, казалось бы, не обусловлена историческими обстоятельствами» [15, c. 209].

Вищеназваний дослідник, аналізуючи цей період княжої кар'єри колишнього переяславського князя, звертає увагу на такі моменти. На час першого запрошення Михайла Всеволодовича на новгородський стіл, він спокійно й без конкурентів перебував на княжому столі Чернігова, поєднуючи у собі відносну молодість та певний військово- 
адміністративний досвід. Чого варта лише участь у сумнозвісній битві на р. Калка у 1223 р. Але це не завадило йому 1224 p. несподівано прийняти запрошення на новгородський стіл, після нічної втечі звідти Всеволода Юрійовича, сина володимиросуздальського князя Юрія Всеволодовича. Михайло Всеволодович на чолі чернігівської дружини прийшов до новгородського володіння Торжка допомагати Юрію Всеволодовичу повернути його сина на стіл Новгорода, й не встиг оговтатись як сам став новгородським князем. Це був результат компромісу між новгородцями та Юрієм Всеволодовичем, бо перші уперлися й стояли на своєму, і Юрій вирішив посадити на цей неспокійний, але бажаний, стіл брата своєї дружини. Чому на це погодився Михайло Всеволодович, якому було досить комфортно і у Чернігові, - нам зараз складно зрозуміти. Як вважає П.П. Толочко, цей чернігівський князь погодився бути ще й новгородським князем «за сумісництвом» [15, с. 211].

Новгородське княжіння спочатку складалося для Михайла Всеволодовича наче й непогано, однак 1225 р. він знову ж таки несподівано вирішив повернутися до Чернігова. Спроби новгородців умовити його залишитися не дали ніяких результатів. Очевидно, він зробив цей крок за домовленістю з Юрієм Всеволодовичем, бо наступного року останній разом зі своїм племінником Васильком Костянтиновичем приходив допомагати чернігівському князю проти Олега курського. Після цього дружні стосунки було закріплено одруженням вищеназваного ростовського князя Василька Костянтиновича на доньці Михайла Всеволодовича Марії. Від цього шлюбу пішла династія князів ростовських, а сама Марія, яка прожила несподівано довге життя, у майбутньому заклала підвалини формування культу свого батька як мученика за віру: «Считается, что инициатором почитания «Мучеников Михаила, князя Черниговского, и боярина его Феодора» была дочь Михаила Мария (ум. 1271 г.), мать Бориса и Глеба Васильковичей, князей ростовских. Вскоре в его честь был возведен в Ростове деревянный храм, сгоревший от удара молнии в 1288 г. Такая скорость для утверждения нового праздника весьма необычна и отражает острое стремление семьи Васильковичей закрепить новый культ. По их инициативе была создана также «Повесть об убиении Михаила Черниговского», сохранившаяся в большом количестве списков как в составе летописей, так и отдельно» $[18$, с. 264].

Повертаючись до новгородської «історії» Михайла Всеволодовича, принагідно зазначимо, що вона була тісно пов'язана ще з одним колишнім князем Переяславля Руського, який також випив до дна свою гірку чашу стосунків 3 із монголо-татарами, хоч $\mathrm{i}$ найпершим із руських князів поїхав у Орду за ярликом на свої ж землі - Ярославом Всеволодовичем. Цей, за висловом Ю.О. Лимонова, розумний і неспокійний князь [7, c. 109], якого П.П. Толочко вважає одним із найбільш яскравих державних діячів Русі першої половини XIII ст. [15, с. 222], перебував на новгородському столі до 1228 р., після чого пішов звідти назад у свій Переяславль Заліський, залишивши у Новгороді двох своїх малолітніх синів. Такий завуальований шантаж дав прямо протилежні наслідки - після заколоту й зміни тисяцького синам Ярослава Всеволодовича довелося втікати 3 Новгорода, а новгородці вдруге запросили до себе Михайла Всеволодовича. Незважаючи на перешкоди з боку попередника, Михайло Всеволодович все ж вдруге зайняв новгородський стіл, одразу розпочавши низку реформ та змін у Новгороді. Перш за все, він звільнив від даней на 5 років збіглих новгородських смердів, підтвердивши попередні норми для всіх інших. Крім того, з метою запобігти розграбуванню майна прихильників попереднього князя, вони «добровільно» віддали свої кошти у загальноміську казну, якими було профінансовано спорудження великого мосту через р. Волхов.

Не змусили себе довго чекати й зміни у новгородській адміністрації - новим посадником замість Іванка Дмитровича став Внізд Водовик. Тисяцького новгородці змінили самі ще до приходу князя у місто. Новгородський архієпископ Арсеній також втратив свою кафедру, оскільки отримав ії у свій час, на думку мешканців міста, за хабар, насильно відправивши у монастир колишнього архієпископа Антонія. Останнього знову 
повернули на новгородську кафедру, але через його немічний стан мусили приставити до нього двох опікунів. Проблему фактичної відсутності у Новгороді легітимного архієпископа було вирішено за ініціативи Михайла Всеволодовича, й за допомогою жеребу з трьох кандидатів обрано новим архієпископом Спиридона - диякона церкви святого Георгія. Однак, одразу після обрання архієпископа Михайло Всеволодович, узявши із собою шістьох знатних новгородців, пішов до Чернігова, залишивши у Новгороді свого малолітнього сина Ростислава. Як вважає П.П. Толочко, складається враження, «что стороны заключили какое-то соглашение и гарантировали его исполнение взаимным присутствием заложников. Со стороны Михаила это, несомненно, было обещание новгородцам вернуть захваченные Ярославом волости. Возможно, и при помощи военной силы, которую он, наверное, надеялся получить от своей «братии». ... Реальная жизнь внесла существенные коррективы в планы Михаила Всеволодовича. Подвигнуть на военный поход южнорусских князей против Ярослава ему не удалось. Пришлось ограничиться дипломатическим демаршем» [15, с. 216-217].

Незважаючи на фактичний провал усієї цієї затії зі спробою налякати Ярослава Всеволодовича й повернути загарбану ним новгородську волость, Михайло Всеволодович спокійно повернувся до Новгорода, влаштував там постриги своєму сину Ростиславу, й разом з архієпископом Спиридоном посадив його замість себе на новгородський стіл й 3 почуттям виконаного обов'язку пішов до Чернігова, знову пообіцявши новгородцям виступити в похід на Ярослава. Однак не усім новгородським мужам подобалися такі дії Михайла Всеволодовича, й після його виходу у місті спалахнув заколот. Його ледве вдалося придушити, але не надовго. Новий заколот відбувся після того, як молодий княжич Ростислав та архієпископ виїхали у Торжок. Нескладно здогадатися, чиї прихильники стояли за усіма цими справами - Ярослава Всеволодовича, який після «зачистки» Новгорода від людей Михайла Всеволодовича прибув до міста 30 грудня 1230 p. й урочисто вступив на новгородський стіл на Ярославовому дворі.

Підсумовуючи цю історію, П.П. Толочко пише: «Таким образом, длительное противоборство черниговского князя Михаила Всеволодовича и переяславского Ярослава Всеволодовича за обладание новгородским столом закончилось победой последнего» [15, c. 218].

Подальші події вказували на неминучість військового зіткнення цих двох князівсуперників, однак його вдалося уникнути за посередництвом київського митрополита Кирила, який очолив велике (35 чоловік) посольство від великого київського князя Володимира Рюриковича до володимиро-суздальського князя Юрія Всеволодовича. Це посольство змогло домовитися про мир між Михайлом та Ярославом Всеволодовичами, визнавши, що неправим у їх стосунках був все-таки Михайло.

1234 р. Михайло Всеволодович підтримував Ізяслава Володимировича у його боротьбі з київським князем Володимиром Рюриковичем. П.П. Толочко пише: «У 1234 р., одержавши повідомлення від Володимира Рюриковича про виступ проти Києва чернігівського князя Михайла, Данило негайно рушив свої полки на Русь та обложив Чернігів. Після «лютого бою», в якому було застосовано й тарани (стінобитні машини), Михайло змушений був просити миру. Щоправда, вже в наступному році він і син Мстислава Романовича Ізяслав завдали поразки Володимиру і Данилу й зайняли їхні столи: Михайло сів у Галичі, а Ізяслав - у Києві» [16, с. 136].

У результаті збройного протистояння йому вдалося допомогти Ізяславу заволодіти Києвом, а сам він зайняв Галич. Як вказує Л.В. Войтович, «Продовжуючи політику Ольговичів, боровся за київський престол, одночасно і за галицьку спадщину проти Романовичів - зведених братів своєї дружини, вважаючи свого старшого сина «по кужелю» законним спадкоємцем Романа Мстиславича» [1, с. 408].

У 1236 р. його союзнику не вдалося утримати Київ, і Михайлу Всеволодовичу довелося, найнявши половців, виганяти з Києва свого попередника ще на переяславському столі Ярослава Всеволодовича. Це йому вдалося й він сів на великокняжому престолі у 
Києві, посадивши в Галичі свого сина Ростислава. Однак, невдовзі «розумний i неспокійний» Ярослав Всеволодович у свою чергу теж вигнав його із Києва, й Михайлу Всеволодовичу довелося вести тривалу боротьбу за Київську землю. У 1238 р. він знову зайняв Київ й, на думку В.В. Богуславського, залишався там княжити аж до приходу під Київ монголо-татар [14, с. 728]. Перебуваючи в Києві Михайло Всеволодович встиг ще й забрати у галицького князя Данила Романовича Перемишльську волость. Коли монголотатари під проводом Менгу-хана, розгромивши Чернігів та Переяслав, підійшли до Києва, то Михайло Всеволодович наказав убити їх послів, а сам утік в Угорщину. 3 цього приводу Г.Ю. Івакін зазначає: «Київський великокнязівський стіл зайняв Михайло Всеволодович. 1239 р. після спустошення Переяслава та чернігова до Києва підійшли монгольські війська на чолі з Менгуханом. Менгухан став проти Києва у Городці (сучасна Вигурівщина), краса й велич столичного міста, могутні оборонні споруди справляли на нього належне враження... Він не наважився на штурм міста й спробував «прельстити» великого князя Михайла Всеволодовича. Проте кияни «не послуша его». Монгольські посли були вбиті, а їхнє військо відійшло у поволзький степ. Переляканий князь Михайло втік до Угорщини, можливо він сподівався отримати там військову допомогу» [3, с. 46].

Як пише Д.Г. Хрустальов, «Убийство послов и очевидное неприятие Михаилом примиренческой линии должны были уничтожить для Киева все шансы избежать нападения» [18, с. 209].

На думку П.П. Толочка, з 1235 р. «на київському столі перебували князі, які не лишили помітного сліду в історії. Останнім з них був Михайло Всеволодович. Дізнавшись про нове вторгнення орд Чингізхана, він злякався і залишив Київ, який зайняв Данило Романович, і посадив у ньому свого боярина Дмитрія» [16, с. 136].

Однак, якраз Михайло Всеволодович залишив свій помітний слід в історії, ставши одним із небагатьох руських князів - мучеників за віру періоду монгольського нашестя.

Із Угорщини він пішов у Польщу, до свого «вуя» (дядька по матері) мазовецького князя Конрада I. Не отримавши необхідної підтримки, він був змушений йти на уклін до Данила Романовича, 3 яким не так давно воював за Перемишль. Данило не став пригадувати старих образ і запросив Михайла до себе. В цей час на Волинь прийшла звістка про страшний розгром Києва татарами, й Михайло Всеволодович із сином Ростиславом знову втік до Польщі. Коли татари вийшли за межі Руської землі, близько 1241 р. він повернувся до розгромленого Києва й поселився під Києвом на дніпровському острові, оскільки центральна частина міста була суцільною руїною та пожарищем: «Вернувшись из Польши, Михаил Всеволодович оставил без продолжения установившиеся накануне монгольского нашествия добрые отношения с Даниилом и Васильком. Он прошел Волынские земли, «не показа правды», и занял Киев, откуда послал Романовичам весть о своем вокняжении. ... Непочтительные действия Михаила были не замечены Романовичами. Все оставалось в рамках приличия, которое, как мог, поддерживал и старший Ольгович. Вернувшись к Киеву, он поселился «под» сожженным и опустевшим городом «въ острове». Это соответствовало достигнутым в 1240 г. договоренностям с Даниилом: Михаил получил Киев и более не претендовал на Галич» $[18$, c. 259].

У 1243 р., отримавши звістку про повернення татар із Заходу в Русь, Михайло Всеволодович знову втік до Угорщини. У 1245 р. на церковному соборі в Ліоні з'явився його спеціальний посланець - ігумен Петро Акерович, який просив у папи Інокентія IV допомоги проти татар. Мабуть, у зв'язку з цим, після повернення до Русі, його було викликано в ставку хана Бату, якому, очевидно, стало відомо про такі дії князя Михайла. Тоді ж він поїхав у Сарай, намагаючись виправдатись перед ханом та отримати від нього ярлик на Чернігівське князівство. Як пише Д.Г. Хрустальов, «На поклон к хану уже ездил великий князь Ярослав, ставший верным вассалом и союзником Бату. Туда же отправился беспокойный Михаил Черниговский, никогда не отличавшийся дипломатическим талантом» $[18$, с. 274$]$. 
Однак, 20 вересня 1246 р. Михайло Всеволодович був убитий татарами в Орді. Згідно 3 літописом, ...заколеннй вүв він веззаконннм АОМаном, пүтнвАьцем нечестнвн, і 3 ннм заколеннй вүв воярнн його Федір [8, с. 401]; Мнхайма [Всеволодовнча], князя чернігівськоГО, якнй не поклоннвся күЩу, із йогО воярнном Федором вонн ножем закололн...» «[8, с. 406]. Очевидець цієї події - папський посол Плано Карпіні - дещо інакше описав його смерть: «Нещодавно сталося так, що Михаїла, який був одним з великих князів руських, коли він прибув на уклін до Бату, вони примусили раніш пройти між двох вогнів; опісля вони сказали йому, щоб він поклонився на південь Чингізхану. Той відповів, що охоче поклониться Бату і навіть його рабам, але не поклониться зображенню мертвої людини, так як християнам цього робити не слід. I після неодноразових вказівок йому поклонитись і його небажання вищеназваний князь передав йому через сина Ярослава, що він буде убитий, якщо не поклониться. Той відповів, що краще бажає померти, ніж зробити те, що не слід. I Бату послав одного охоронця, який бив його п’яткою в живіт навпроти серця так довго, доки той не помер. Тоді один з його воїнів, який стояв поряд, ободряв його, кажучи: «Будь стійким, так як ця мука недовго для тебе продовжуватиметься й відразу наступить вічне блаженство». Після цього йому відрізали голову ножем, і у вищезгаданого воїна голову також відрізали ножем» [2, с. 168]. Під воїном, очевидно, Плано Карпіні мав на увазі боярина Федора.

На думку Д.Г. Хрустальова, «Роль черниговского князя после монгольского нашествия предстает незавидной. Его земли разорены, а противники усилились. Даже собственный сын после неудачной авантюры в Галиции покинул его, отказался содействовать возвращению столь желанного Киева. Батый более полагался на верного Ярослава, нежели на престарелого и непостоянного Ольговича. Все злоключения Михаила в ханской ставке напоминают хорошо подстроенную провокацию, в основе которой была тонкая игра на чувствах православного воина. В итоге князь принял мученическую смерть и фактически завершил славную двухвековую историю черниговской династии Ольговичей» [18, с. 276].

Згідно $з$ джерелами, останки Михайла Всеволодовича було викинуто собакам, однак супутники князя, що залишились живими, зберегли їх i привезли у Чернігів, де й поховали. Через деякий час останки князя Михайла та боярина Федора було перевезено до Москви й перезахоронено у спеціально для цього влаштованому храмі над Тайницькими воротами в Кремлі (фактично, їх було викрадено московитами). Як зазначає С. Келембет, «офіційна канонізація Михайла Чернігівського, як загальноруського святого, була здійснена лише в 1547 р. У 1578 р., за наказом царя Івана Грозного, мощі Михайла Всеволодовича було перенесено з чернігівського Спаського собору до Москви, де перепоховано у спеціально збудованому на Іванівській площі Кремля соборі Чернігівських чудотворців. У 1681 р. цю будівлю розібрали, мощі перенесли до Архангельського собору, а в 1683 р. повернули вже до нового храму, зведеного над Тайницькими воротами. У 1769 р. й цю будівлю призначили до знесення, і тоді ж виявилося, що у мідній гробниці зберігалися рештки одного кн. Михайла, без боярина Федора. Наступного року мощі перенесли до Стретенського собору, а в 1774 р. - до Архангельського, родової усипальниці московських великих князів та царів; там вони знаходяться і понині (хоча протягом ХХ ст. не раз переміщувалися 3 місця на місце)» [4, c. 15].

За різними джерелами, Михайло Всеволодович мав кількох синів: Ростислава та Романа (Старого), відомих з літописів, Мстислава, Симеона (Семена) та Юрія (Георгія), відомих 3 «Бархатної книги» [8, с. 401, 515].

Стосовно пізніх родословців XVI ст., то необхідно мати на увазі, що надзвичайна популярність постаті Михайла Чернігівського у цей період призвела до того, що усі служилі верховські князі записалися у родословці як його нащадки - «плем'я Михайла Чернігівського»: «От сыновей Михаила Черниговского - третьего, Семена, князя глуховского и новосильского, четвертого, Мстислава, князя карачевского, и пятого, Юрия, 
князя торусского и оболенского, пошли многочисленные дворянские роды князей Белевских, Воротынских, Одоевских (а также князей Одоевских-Масловых), Мосальских (с их ветвями - князей Кольцовых-Мосальских, Литвиновых-Мосальских, КлубковыхМосальских, Мосальских-Корецких и дворян Мосальских-Рачко), Хотетовских, дворян Бунаковых, князей Огинских, Пузын, дворян Сатиных, князей Горчаковых, Елецких, Звенигородских (с их ветвями князей Звенигородских-Спячих, Рюминых, Барашевых, Шистовых, Звенцовых, Токмаковых и Ноздреватых), Болховских, Мезецких, Волконских, Барятинских, Мышецких, Оболенских (с их ветвями - князей Курлятевых, Ноготковых, Стригиных, Ярославовых, Нагоевых, Телепневых, Турениных, Репниных, Пенинских, Горенских, Тюфякиных, Щепиных, Золотых, Серебряных, Лыковых и КашиныхОболенских, а также князей Оболенских-Нелединских-Мелецких), Долгоруковых (а также светлейших князей Юрьевских), Щербатовых и Тростенских.

Это первый большой Дом потомков Рюриковичей. Однако старшей его ветвью были угасшие князья Осовицкие, потомки второго сына Михаила черниговского - брянского князя Романа (старший сын Михаила Ростислав перебрался в Венгрию, где и осталось его потомство)» [11, с. 153].

Генетичні дослідження XXI ст. показали, що насправді представники цього клану не походять по чоловічій лінії від того ж предка, що й Мономаховичі [19].

Крім синів, Михайло Всеволодович також мав двох дочок: Марію (дружину ростовського князя Василька Костянтиновича) та Феодулію (в черницях Сфросинію). Вона була нареченою княжича Федора Ярославича, який помер молодим, перед самим весіллям з нею. Існує «Житіє Феодулії», яка з 1227 р. й до самої своєї смерті 25 вересня 1250 р. була черницею у Суздалі й також, як і її батько, занесена до лику святих [8, с. 401, $515]$.

Агіографічні джерела та літописи підкреслюють, що Михайло Всеволодович відмовився виконати язичницький обряд очищення вогнем. Таким чином, його загибель це один з рідкісних випадків смерті від рук татар через власне релігійні переконання [13]. I.M. Данілевський вказує, що Михайло Всеволодович відмовлявся проходити через вогонь, оскільки такі дії відносяться у Біблії до числа тяжких гріхів [2, с. 341]. Однак він все ж таки зробив це, як свідчить Плано Карпіні. Лише коли він відмовився вклонитися зображенню Чингізхана, його було убито. Але, як зазначає В.В. Богуславський, значно вагомішими причинами його вбивства були знищення татарських посланців у Києві та спроба організації антитатарської коаліції на Заході, про що без сумніву знав хан Бату [14, с. 729]. Монголо-татари такого не прощали.

Розглядаючи політичну історію руської канонізації XI-XVI ст., О.С. Хорошев звернув увагу на кілька важливих моментів, дотичних до нашої теми. Перш за все він відзначив, що звернення до канонізації другої половини XIII - початку XIV ст. показує, що вона репрезентована широким князівським «потоком». Серед цих князів та членів їх сімей $є$ і Михайло Всеволодович. Політичний сенс уведення князів до лику руських святих розкривається обставинами їх загибелі - більшість князів вважаються святими мучениками: «Наиболее подробно рассказано о «мученичестве» Михаила Всеволодовича Черниговского, казненного с боярином Федором в Орде 20 сентября 1246 г. Князь не обнаружил героизма в годы военной опасности. Во время батыева нашествия он бежал в Венгрию, оставив без обороны Киев. Вернувшись на родину, вокняжился в разоренном Киеве и был вызван в Орду. Князь знает, что в Орде ему придется пройти «сквозь огонь» и поклониться «кусту и огневи, и идолом их». Михаил готов поклониться Батыю: «Понеже поручил ти (хану - А. Х.) есть царство света сего», но проходить между огнями и кланяться языческим богам отказывается. За отказ выполнить особый ритуал вельможа Батыя Елдега приказывает «мучить» князя «различными муками» и отрубить ему голову. Поступок своего господина повторил боярин Федор. Причем казнь совершил не ордынец, а «некто, бывший христианин..., отвергшийся... веры». Гибель в Орде князя и боярина трактуется в житии как подвиг и страдание за веру» [17, с. 76-77]. 
Названий автор зазначає, що пізніше, в історичних умовах XIV ст., проложне житіє Михайла Черніговського було деталізоване й доповнене «подробицями», які надавали агіографічному твору характер політичного протесту, животрепетної розповіді про жорстокість поневолювачів та непохитну гордість руського князя, який жертвує життям за честь своєї землі. Але для того, щоб цей мотив стало чутно в агіографічному творі як набат, був потрібен підйом національно-визвольного руху руського народу в другій половині XIV ст. При поверхневому погляді на історію канонізації князів-мучеників складається враження, що руська православна церква притримується того ж політичного спрямування, тієї ж патріотичної мотивації, яка характерна для громадянської літератури Русі XIII - початку XIV ст. Це враження зникає при зверненні до історії канонізації: «Ни один из перечисленных святых князей не продемонстрировал военного мужества, необходимого для гражданского звучания культа. Их «подвиг» не представляет никакой «военной угрозы» золотоордынским ханам. Более того, церковь всячески стремится обелить золотоордынских ханов в момент «мученического подвига» святых князей: Михаил Черниговский подвергнут пыткам и казни не по приказу Батыя, но по указанию вельможи Елдега, а палач князя - бывший христианин.

Подобный идеологический подтекст политической канонизации определяется отношением русской церкви к подлинным образцам политического и военного мужества. Если бы политическая доктрина церковной организации преследовала идею прославления активной борьбы с поработителями, она могла прославить более яркие эпизоды» [17, c.77].

Далі О.С. Хорошев констатує, що духовенство, вдаючись до канонізації, було далеке від думки закликати руських людей до об’єднання своїх сил для відсічі «поганим». Навпаки, каяття, смирення і покора - ось основна ідея політичної канонізації XIII початку XVI ст. [17, с. 78].

Згадуючи про князів, «убиенных от татар», О.В. Русина пише: «Деякі знайшли свою смерть в Орді, куди мусили їздити «на поклон», щоб дістати ярлики на власні княжіння. 3поміж них тільки один - Михайло Всеволодич Чернігівський - отримав «офіційний» ореол мученика: був канонізований як страстотерпець за віру. Згідно з літописами й «Житієм» князя, у 1245 р., коли він прибув до ставки Батия, «прося волости своея от него», той нібито став змушувати його «поклонитися идолам». Михайло ж, із християнською покорою приймаючи нові політичні реалії, відмовився поступитися своїми релігійними принципами й відповів Батию: «Аще (оскільки - авт.) Бог нас передал и власть нашу, грехов ради наших, во руце ваши, тебе кланяемся и честь приносим, а закону (вірі - авт.) отцов твоих и твоему богонечестивому повелению не кланяемся». За це князь був підданий тортурам і вбитий. Така ж доля спіткала і його супутника боярина Федора.

Ця суто агіографічна версія загибелі князя не задовольняє більшість істориків, котрі шукають у діях Батия політичне підгрунтя; власне, вона здавалася сумнівною й деяким із сучасників. Карпіні, зокрема, вважав, що влаштоване Батиєм «випробування віри» мало замаскувати його справжні наміри: у будь-який спосіб звести князя зі світу, щоб опанувати його землі; при цьому францісканець покликався на властиве монголам бажання самим порядкувати на завойованих обширах. Безумовно, італійцю можна закинути схильність до надто широких узагальнень (чи, словами М. Грушевського, до «неоправданої генералізації фактів, що могли траплятись хіба одинично і спорадично»), однак не слід забувати, що Михайло був не єдиним чернігівським князем, котрий загинув в Орді: майже одночасно там «убиен бысть от Батыя князь Андрей Мстиславич», якого Карпіні виводив з «Чернігова, що на Русі» [12, с. 19-20].

Ще один важливий момент, який досі викликає дискусії серед науковців - це точна дата загибелі князя. Про це Д.Г. Хрустальов зазначає: «Традиционно считается, что князь погиб 20 сентября 1246 (6754) г. Эту дату используют как историки-исследователи, так и священнослужители. 
Однако ближайшее рассмотрение источников не позволяет согласиться с этой датировкой однозначно. В Новгородской первой летописи смерть Михаила отмечена 18 (или 8) сентября 1245 (6753) г., в Софийской первой - 23 сентября 1245 (6753) г., а в Воскресенской - 23 сентября 1246 (6754) г. Если признать более достоверной действительно используемую в «Повести об убиении Михаила» и традиционную дату 20 сентября, то год смерти князя следует вынести за скобки. Наиболее часто встречается 1245 (6753) г., чуть реже 1246 (6754) г., а порою и 1247 (6755) г. Для уточнений попробуем выбрать некий временной ориентир, на который вполне можно будет положиться. О смерти Михаила, произошедшей где-то на Волге, сообщить было практически некому, да и интерес к точной дате могли проявить только в чернигове и Ростове. Фактически мы располагаем известиями только из последнего города, куда информация попала, скорее всего, очень не скоро и «через третьи руки». Другое дело известие о смерти великого князя Ярослава Всеволодовича на пути из Каракорума. Его можно датировать сразу по нескольким независимым источникам (русские летописи, записки Плано Карпини), к тому же в источниках никогда не бывает расхождений в этой дате - 30 сентября 1246 г. При этом смерть Ярослава в летописях всегда отмечена после смерти Михаила, что естественно, но иногда эти сообщения разнесены в разные погодные статьи, что заставляет призадуматься. Вероятно, о точной дате убийства Михаила велись разные толки, но позднее она была привязана к комплексу известий о коварстве монгольских ханов, травивших и губивших русских князей. Поэтому гибель Михаила и Ярослава, давних врагов, была совмещена в некоторых сочинениях в одну статью, к тому же весьма бедную на другие события. Последовательность изложения в летописце Даниила Галицкого также заставляет удревнить поездку Михаила к Батыю.... Отъехать на Волгу Михаил имел возможность начиная с весны 1244 г. Ход изложения в Ипатьевской летописи ведет к тому, что эта поездка состоялась сразу после возвращения Михаила из Венгрии, то есть в том же 1244 г. Возможно, следует несколько более широко разносить события этих лет, и тогда мы выйдем на вполне подтверждаемую в письменных источниках дату 1245 (6753) г., при том что 1246 г. остается слишком удаленным, как и все последующие» [18, с. 264-265].

Отже, колишній переяславський князь Михайло Всеволодович, який зовсім недовго перебував у Переяславі, за свого життя не зміг набути слави своїх відомих попередників на княжому столі Переяславля Руського - Всеволода Ярославича, Володимира Мономаха, Ізяслава Мстиславича чи Володимира Глібовича. Однак обставини його смерті як мученика за віру дозволили йому стати одним із найвідоміших руських князів та бути зарахованим до лику святих. Цей статус посприяв тому, що у XVI ст. Михайло Всеволодович «обзавівся» величезною кількістю нащадків за рахунок княжих верховських родів 3 півночі колишньої Чернігівської землі.

\section{ДЖЕРЕЛА ТА ЛІТЕРАТУРА}

1. Войтович Л.В. Княжа доба на Русі: портрети еліти. Біла Церква, 2006. 784 с.

2. Данилевский И.Н. Русские земли глазами современников и потомков (XIIXIV вв.). Москва, 2001. 389 с.

3. Івакін Г.Ю. Історичний розвиток Києва XIII - середини XVI ст. (історикотопографічні нариси). Київ, 1996. 271 с.

4. Келембет С. Михайло Всеволодович, великий князь Чернігівський і Київський: деякі питання походження, біографії та складу родини // Сіверянський літопис. 2017. № 12. C. $11-19$.

5. Коринный Н.Н. Переяславская земля, X - первая половина XIII века. Киев, 1992. $312 \mathrm{c}$

6. Котляр М.Ф. Михаїл Всеволодич // Енциклопедія історії України: у 10 т./ редкол.: В.А. Смолій (голова) та ін. ; Інститут історії України НАН України. Київ, 2009. Т. 6 : Ла Mi. C. 687. 
7. Лимонов Ю.А. Владимиро-Суздальская Русь. Ленинград, 1987. 216 с.

8. Літопис Руський за Іпатським списком. Київ, 1989. 591 с.

9. Ляскоронский В.Г. История Переяславльской земли с древнейших времен до половины ХІІІ ст. Киев, 1903. 422 с., карта. $85 \mathrm{c}$.

10. Павленко С. Князь Михайло Чернігівський та його виклик Орді. Чернігів, 1996.

11. Пчелов Е.В. Рюриковичи. История династии. Москва, 2001. 479 с.

12. Русина О.В. Україна під татарами і Литвою // Україна крізь віки. Т.6. Київ, 1998. $320 \mathrm{c}$.

13. Сказание об убиении в орде князя Михаила черниговского и его боярина Феодора // Библиотека литературы Древней Руси / РАН. ИРЛИ; под ред. Д.С. Лихачева, Л.А. Дмитриева, А.А. Алексеева, Н.В. Понырко. T.5: XIII век. URL: http://lib.pushkinskijdom.ru/Default.aspx?tabid=4957 (дата звернення: 12.10.2018).

14. Славянская энциклопедия. Киевская Русь - Московия. Москва, 2002. Т.1. 784 с.

15. Толочко П.П. Киев и Новгород в Х-ХІІІ вв. Киев, 2018. 255 с.

16. Толочко П.П. Київська Русь. Київ, 1996. 360 с.

17. Хорошев А.С. Политическая история русской канонизации (XI-XVIвв.). Москва, 1986. 206 с.

18. Хрусталев Д.Г. Русь и монгольское нашествие (20-50-е гг. ХIIIв.). СанктПетербург, 2013. 416 с.

19. Rurikid Dynasty DNA Project. URL: https://www.familytreedna.com/groups/rurikid/about/news (дата звернення: 12.10.2011).

\section{REFERENCES}

1. Voitovych, L.V. (2006). Kniazha doba na Rusi: portrety elity [Prince's day in Rus': portraits of the elite]. Bila Tserkva [in Ukrainian].

2. Danilevskij, I.N. (2001). Russkie zemli glazami sovremennikov $i$ potomkov (XII$X I V v v$.$) [Russian lands through the eyes of contemporaries and descendants (XII-XIV$ centuries)]. Moskva [in Russian].

3. Ivakin, H.Iu. (1996). Istorychnyi rozvytok Kyieva XIII - seredyny XVI st. (istorykotopohrafichni narysy) [Historical development of Kyiv in the XIII - mid-sixteenth centuries (historical and topographical essays)]. Kyiv [in Ukrainian].

4. Kelembet, S. (2017). Mykhailo Vsevolodovych, velykyi kniaz Chernihivskyi i Kyivskyi: deiaki pytannia pokhodzhennia, biohrafii ta skladu rodyny [Mykhailo Vsevolodovych, Grand Duke Chernihiv and Kyiv: some questions about the origin, biography and composition of the family]. Siverianskyi litopys, 1-2, 11-19 [in Ukrainian].

5. Korinnyj, N.N. (1992). Perejaslavskaja zemlja, X - pervaja polovina XIII veka [Pereiaslavl land, $X$ - the first half of the 13th century]. Kiev [in Russian].

6. Kotliar, M.F. (2009). Mykhail Vsevolodych [Mykhailo Vsevolodych]. Entsyklopediia istorii Ukrainy: u 10 t./ redkol.: V.A. Smolii (holova) ta in.; Instytut istorii Ukrainy NAN Ukrainy, 6: La - Mi. Kyiv, 687 [in Ukrainian].

7. Limonov, Ju.A. (1987). Vladimiro-Suzdal'skaja Rus' [Vladimir-Suzdal Rus']. Leningrad [in Russian].

8. (1989). Litopys Ruskyi za Ipatskym spyskom [Chronicle of Rus' on the Hipat List]. Kyiv [in Ukrainian].

9. Ljaskoronskij, V.G. (1903). Istorija Perejaslavl'skoj zemli s drevnejshih vremen do poloviny XIII st. [The history of Pereiaslavl land from ancient times to half of the XIII century]. Kiev [in Russian].

10. Pavlenko, S. (1996). Kniaz Mykhailo Chernihivskyi ta yoho vyklyk Ordi [Prince Mykhailo of Chernihiv and his challenge to the Horde]. Chernihiv [in Ukrainian].

11. Pchelov, E.V. (2001). Rjurikovichi. Istorija dinastii [Rurikovich. Dynasty history]. Moskva [in Russian]. 
12. Rusyna, O.V. (1998). Ukraina pid tataramy i Lytvoiu [Ukraine under Tatars and Lithuania]. Ukraina kriz viky, 6. Kyiv [in Ukrainian].

13. Skazanie ob ubienii v orde knjazja Mihaila chernigovskogo i ego bojarina Feodora [The legend of the murder in the Horde of Prince Mykhailo of Chernihiv and his boyar Theodore] // Biblioteka literatury Drevnej Rusi / RAN. IRLI; pod red. D.S. Lihacheva, L.A. Dmitrieva, A.A. Alekseeva, N.V. Ponyrko. T.5: XIII vek. Retrieved from: http://lib.pushkinskijdom.ru/Default.aspx?tabid=4957 [in Russian].

14. (2002). Slavjanskaja enciklopedija. Kievskaja Rus' - Moskovija [Slavic encyclopedia. Kievan Rus' - Muscovy]. Moskva [in Russian].

15. Tolochko, P.P. (2018). Kiev i Novgorod $v$ X-XIII vv. [Kiev and Novgorod in the 10 th -13 th centuries]. Kiev [in Russian].

16. Tolochko, P.P. (1996). Kyivska Rus' [Kievan Rus']. Kyiv [in Ukrainian].

17. Horoshev, A.S. (1986). Politicheskaja istorija russkoj kanonizacii (XI-XVI vv.) [Political history of Russian canonization (XI-XVI centuries)]. Moskva [in Russian].

18. Hrustalev, D.G. (2013). Rus'i mongol'skoe nashestvie (20-50-e gg. XIII v.) [Rus' and the Mongol invasion (20-50s of the 13th century)]. Sankt-Peterburh [in Russian].

19. Rurikid Dynasty DNA Project.

Retrieved

from:

https://www.familytreedna.com/groups/rurikid/about/news.

Одержано 01.02.2019.

УДК 930.1:329(477)«18»

\section{Нагайко Тарас,}

кандидат історичних наук,

завідувач науково-дослідного відділу

історичного

краєзнавства

HIE3 «Переяслав»,

керівник навчально-наукового центру усної

iсторії

taras.nahaiko@ukr.net

http://orcid.org/0000-0002-1439-3576

Національний історико-етнографічний

заповідник «Переяслав»,

вул. Шевченка, 8, м. Переяслав-

Хмельницький,

Київська обл., Україна, 08400

\section{DOI https://doi.org/10.31470/2415-3567- 2019-45-17-24}

\section{Nahaiko Taras,}

Candidate of Historical Sciences,

Head of the Research Department of Historical Local History NEES «Pereiaslav»,

Head of the Educational and Scientific Center of Oral History

taras.nahaiko@ukr.net

http://orcid.org/0000-0002-1439-3576

National Historical and Ethnographic

Reserve «Pereiaslav»»

8, Shevchenka Str.,

Pereiaslav-Khmelnytskyi,

Kyiv region, Ukraine, 08400

\section{ГРОМАДІВСЬКИЙ РУХ ЯК ФЕНОМЕН НАЦІОНАЛЬНОГО САМОУСВІДОМЛЕННЯ УКРАЇНЦІВ ДРУГОЇ ПОЛОВИНИ ХІХ СТ.}

У статті розглянуто питання, пов'язані з украӥнським громадівським рухом другої половини XIX cm. У ией час з-поміж прогресивних кіл суспільства зріс інтерес до самоусвідомлення етнічних особливостей украӥнського народу. Наукове вивчення історії та культури рідного краю дало подальший поштовх для усвідомлення власних національних рис. Учасники українофільських організацій ставили собі за мету 